\title{
Human Resource Development Issues in the Field of Islamic Astronomy: Analysis of the Langkawi National Observatory, Malaysia
}

\author{
Khadijah Ismail, Fairos Asillam, and Aizan Ali Mat Zin
}

\begin{abstract}
A study by Global Astronomy Survey (GAS) showed that the knowledge and development of astronomy in developing countries is still at a poor level. This stems from the lack of quality of the human resources produced in schools, universities, and even in the observatories across the country as centres for research and astronomy education. This paperwork aims to analyse good human resource development at the Langkawi National Observatory, as the main observatory in Malaysia, particularly as a centre to train skilled human resources in astronomical research. Data collection was done using documentation, interviews and observation at the scene. All data collected have been analysed by inductive, deductive and comparative analyses. As a result, the article proposes a new model regarding the development of human resources in the Langkawi National Observatory to address the issue of the training phase for employees and staffing system.
\end{abstract}

Index Terms-Islamic astronomy, human resource development, Islamic civilization, observatory, malaysia.

\section{INTRODUCTION}

Nowadays, modern and sophisticated technologies have caused great changes in respect of skills development and human resources expertise. Although science and technology assists humans in their daily life, humans need knowledge and skills to manage and use the technology.

For example, in the installation of telescopes at the observatory stations, assembling the telescope is not an easy task, let alone operating the telescope, and, furthermore, the maintenance requires specific knowledge and skills. Therefore, the development of highly skilled employees in observatory stations is essential for the purpose of maintenance.

A study in developing countries by the Global Astronomy Survey (GAS), which was conducted under the cornerstone project of Developing Astronomy Globally (DAG), identified the weaknesses and strengths of development in the field of astronomyin certain developed countries [1]. Eventhough Malaysia was not involved in the survey, based

Manuscript received August 22, 2013; revised November 15, 2013. This work was supported and funded by the Higher Education Sector under Skim LatihanAkademikBumiputra (SLAB), Ministry of Higher Education and University of Malaya.

F. A. Khadijah Ismail and T. C. Aizan Ali Mat Zin are with the Department of Islamic History and Civilization, Academy of Islamic Studies, University of Malaya, 50603 Kuala Lumpur, Malaysia (e-mail: dijahis@gmail.com, aizan@um.edu.my)

S. B. Fairos Asillam is with the Space Science Research Unit (UPSA), Malaysia (e-mail: fairos@angkasa.gov.my). on the analysis conducted by GAS, it was found that Malaysia was still in the second stage in the survey, which comprises countries that have their own astronomical research and communities that understand astronomy, but require support in different aspects, such as funds, education policy and developing policy to enrich the field of astronomy. In Malaysia, the development of astronomical research can be measured by the increased amount of research conducted by undergraduates and postgraduates in the astronomical field [2], [3]. Although universities in Malaysia do not offer a course on astronomy, the awareness to make astronomy a programme and subject at the university and school level has increased, especially among policy makers. In addition, awareness campaigns and understanding about astronomy in schools and university have also been enhanced.

\section{Human Resource DeVelopment IN SCIENCE AND TECHNOLOGY INSTITUTIONS}

Human resource management in Malaysia refers to the policies, practices and systems that are adapted to influence the behaviour, attitude and performance of employees. The core of human resource development in Malaysia also emphasizes increasing the supply of man power in science and technology, which is consistent with the rapid development of knowledge in new science and technology [4]. In line with the strategy that emphasizes the development in science and technology, in April 1986, the Government announced the National Science and Technology Policy. The objective of the policy for science and technology (S\&T) was to promote the application of science and technology as a tool for economic development, improve the physical position and well-being of the people, and also to protect thecountry's sovereignty, which is part of the policy for the socio-economic development of the country.Among the plans to develop the ability of S\&T was the capacity building resources of S\&T for Malaysia, including technical and scientific bodies, research institutes, institutions of higher learning, and also others towards the formation of local technological capacity (develop indigenous technology capacity) [5].

Consistent with the development of the resource capabilities of S\&T, particularly for technical and scientific bodies, the quantity and quality of the Malaysian astronomers and workforce at the observatory as an astronomy laboratory still needs to be improved. Similarly, the workforce in observatories across the nation still requires continuous skills and training. In the area of human 
resource development, the aspects of human resource training or employee recruitment, staffing system and recruitment system areessential in every organization. [4], [6] The training in an organization is an ongoing learning process designed to change the attitudes, and increase the knowledge and skills of employees so that work performance can be increased. In the context of human resource training in the observatory, the analysis regarding the need for training and development, such as the figure below, was analysed by conducting several interviews with the founders of observatories and employees at the selected observatories, as well as the experience of the author who was involved in the initial planning of the establishment of the Langkawi National Observatory.

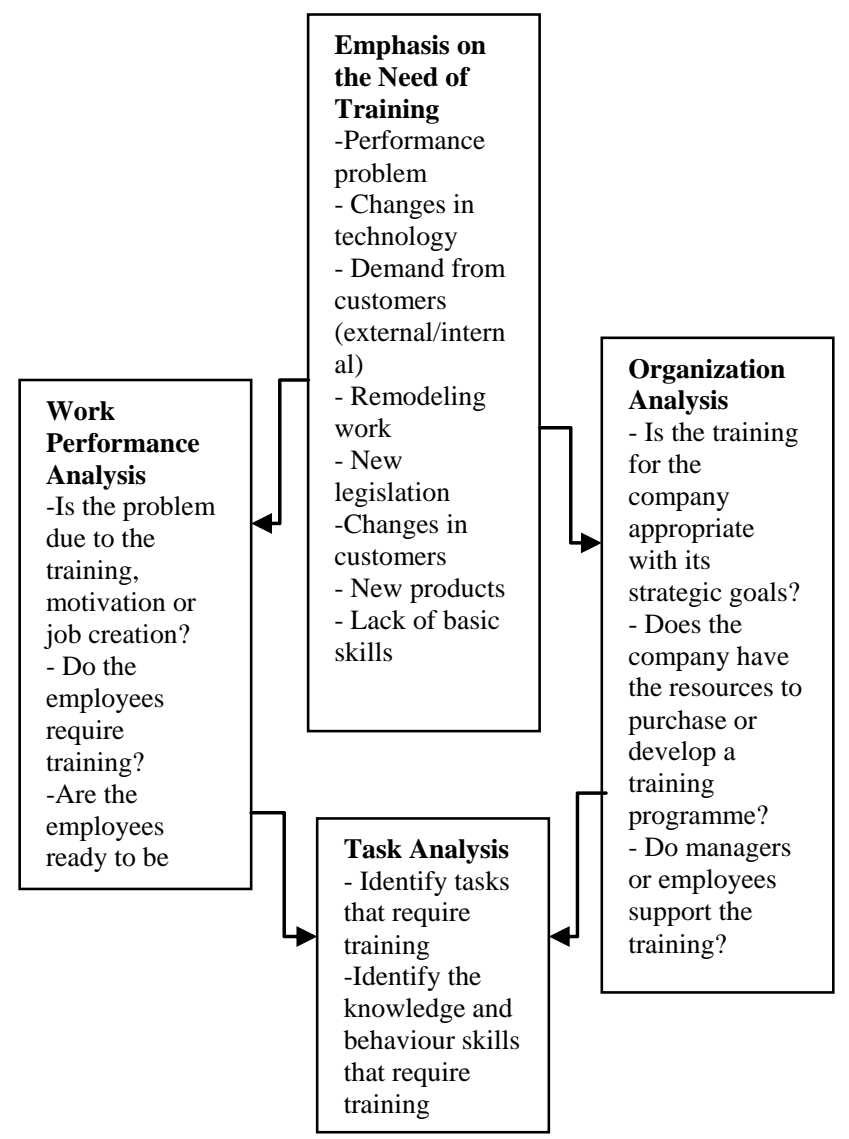

Fig. 1. Analysis for training needs and development [4]

\section{OBSERVATORIES IN MALAYSIA}

An observatory is a place where astronomical observations are carried out, in which, sometimes, the term observatory is used to distinguish between the administrative building and the area for observation [7]. This building is built specifically to observe celestial bodies using equipment, such as optical, radio or infrared telescopes, and for observatories with larger and more sophisticated equipment, the instruments are equipped with spectrographs, astrometry, photometry and other instruments used in the observation [8], [9]. Nowadays, the construction of observatories around the world is usually based on the type of research to be conducted.

The development of astronomical observation is not limited to the Earth, but also the universe. The growth of astronomical observation became rapid after Galileo Galilei used a telescope to observe celestial bodies. Celestial bodies emit electromagnetic waves comprising visible light waves, $\mathrm{X}$-ray waves, gamma ray waves, ultraviolet waves, infrared waves, microwaves, and radio waves [10]. Each electromagnetic wave range can be observed by using specific instrumentation and certain astronomical methods. Humans on Earth can only see in the range of visible light, infrared rays and radio waves, therefore, instruments such as the Hubble telescope, Chandra X-ray telescope and International Space Station, have been sent into space and function as observatories on Earth. There are different types of observatory: those placed on Earth that are used in astronomical research, which are optical telescopes that allow us to see blurry stars more clearly; radio telescopes that allow us to see those radio sources behind the interstellar dust clouds in the Milky Way galaxy that can be observed, and infrared telescopes that create cold images that often cannot be seen, such as cold stars, dust and cold gas associated with the formation of stars, planets and comets. This telescope can work day and night.

TABLE I: LIST OF OFFICIAL AND UNIVERSITY OBSERVATORIES

\begin{tabular}{|c|c|c|}
\hline Observatory & $\begin{array}{l}\text { Main objective of } \\
\text { establishment }\end{array}$ & Authority \\
\hline $\begin{array}{l}\text { Langkawi National } \\
\text { Observatory, Kedah }\end{array}$ & $\begin{array}{lr}\text { Astronomical } & \text { research } \\
\text { and } & \text { expertise } \\
\text { development } & \end{array}$ & $\begin{array}{l}\text { National Space } \\
\text { Agency } \\
\text { (ANGKASA), } \\
\text { Ministry of Science, } \\
\text { Technology and } \\
\text { Innovation } \\
\text { (MOSTI) }\end{array}$ \\
\hline $\begin{array}{lr}\text { Baitul } & \text { Hilal } \\
\text { Observatory, } & \text { Teluk } \\
\text { Kemang, } & \text { Negeri } \\
\text { Sembilan } & \end{array}$ & $\begin{array}{l}\text { 1. Education for the } \\
\text { community } \\
\text { 2. Sighting of new moon } \\
\text { 3. Astronomical research }\end{array}$ & $\begin{array}{lr}\text { Negeri } & \text { Sembilan } \\
\text { Mufti's Department }\end{array}$ \\
\hline $\begin{array}{l}\text { Al-Khawarizmi } \\
\text { Astronomy Complex, } \\
\text { Melaka }\end{array}$ & $\begin{array}{l}\text { 1. Education for the } \\
\text { community } \\
\text { 2. Sighting of new moon } \\
\text { 3. Astronomical research }\end{array}$ & $\begin{array}{l}\text { Malacca Mufti's } \\
\text { Department }\end{array}$ \\
\hline $\begin{array}{lr}\text { Sheikh } & \text { Tahir } \\
\text { Astronomical } & \text { Centre, } \\
\text { Pulau Pinang } & \end{array}$ & $\begin{array}{l}\text { 1. Sighting of new moon } \\
2 \text {. Astronomical } \\
\text { research } \\
\text { 3. Education for the } \\
\text { community }\end{array}$ & $\begin{array}{l}\text { Penang Mufti's } \\
\text { Department }\end{array}$ \\
\hline $\begin{array}{l}\text { Al-Biruni } \\
\text { Observatory, Sabah }\end{array}$ & $\begin{array}{l}\text { 1. Sighting of new moon } \\
\text { 2. Astronomical } \\
\text { research } \\
\text { 3. Education for the } \\
\text { community }\end{array}$ & $\begin{array}{l}\text { Sabah Mufti's } \\
\text { Department }\end{array}$ \\
\hline $\begin{array}{l}\text { National Planetarium } \\
\text { Observatory, } \quad \text { Kuala } \\
\text { Lumpur }\end{array}$ & $\begin{array}{lll}\text { Education } & \text { and } & \text { public } \\
\text { awareness } & & \text { forthe } \\
\text { community } & & \end{array}$ & $\begin{array}{l}\text { National Space } \\
\text { Agency } \\
\text { (ANGKASA), } \\
\text { Ministry of Science, } \\
\text { Technology and } \\
\text { Innovation } \\
\text { (MOSTI) }\end{array}$ \\
\hline Selangor Observatory & $\begin{array}{l}\text { 1. Sighting of new moon } \\
\text { 2. Astronomical research } \\
\text { 3. Education for the } \\
\text { community }\end{array}$ & $\begin{array}{l}\text { Selangor Mufti's } \\
\text { Department }\end{array}$ \\
\hline $\begin{array}{l}\text { UniSZA Observatory, } \\
\text { Terengganu }\end{array}$ & $\begin{array}{l}\text { 1. Sighting of new moon } \\
\text { 2. Astronomical research } \\
\text { 3. Education for the } \\
\text { community }\end{array}$ & $\begin{array}{l}\text { Universiti } \text { Sultan } \\
\text { ZainalAbidin } \\
\text { (UniSZA) }\end{array}$ \\
\hline $\begin{array}{l}\text { Physics Observatory, } \\
\text { UniversitiMalaya, } \\
\text { Kuala Lumpur }\end{array}$ & $\begin{array}{l}\text { 1. Astronomical research } \\
\text { 2. Education for the } \\
\text { community }\end{array}$ & $\begin{array}{ll}\text { Universiti } & \text { of } \\
\text { Malaya (UM) } & \end{array}$ \\
\hline
\end{tabular}


In Malaysia, the function of an observatory depends on the objectives and reasons why the observatory was built. At the time this paper was written, there were seven official observatories and two observatories under the jurisdiction of the university that function as the place to conduct research and for educational purposes for students and the general public. The official observatories are those under the supervision of the State Falak Department and also the National Space Agency (ANGKASA), Ministry of Science, Technology and Innovation (MOSTI), which does not include private observatories. The table below shows the main objectives of each observatory and the jurisdiction of the particular department or university it is under. However, to the best knowledge the authors, there are nine private observatories built by amateurs around Malaysia which are not included in this paper.

\section{The LANGKAWI NATIONAL OBSERVATORY AND HuMAN RESOURCE TRAINING}

The Langkawi National Observatory is the Malaysian national observatory under the National Space Agency (ANGKASA), Ministry of Science, Technology and Innovation (MOSTI). After several resolutions that demanded the establishment of a national observatory in a series of telescope seminars that were held by Space Science Studies Division (BAKSA), which is the former name of ANGKASA, the Langkawi National Observatory was established and has been in operation since 2006. The official launch was presided overby the Minister of Science, Technology and Innovation, Datuk Seri Dr Maximus Ongkili on 28 January 2011. Before this, an observatory at the National Planetarium, Kuala Lumpur, concentrated more on education for the public, while the observatory at Bukit Malut, Langkawi, functioned as an observatory for astronomical research that is open to students and researchers from universities, as well as local and overseas personnel. The National Planetarium in Kuala Lumpur is situated in the middle of the city, and, thus, it is not really suitable for conducting research due to the light pollution that interferes with the research while obtaining data regarding objects in space. At the Langkawi National Observatory, observants can operate a remote-controlled telescope and CCD camera fromany distant place, either directly or using robotic technology. The robotic telescope system is supported by the global Internet network connection, which provides a greater advantage in the expansion of knowledge pertaining to astronomy. [11]

The Langkawi National Observatory plays an important role along with other observatories to monitor the safety of Earth by monitoring space, especially for space rocks that pose threats to Earth (near Earth Object Programme). In addition, these observatories provide opportunities to scientists, astronomists and students to use them in their research. The data from the Langkawi National Observatory have been shared with other researchers throughout the country.

The staff at the Langkawi National Observatory consists of 7 employees -2 research officers, 1 assistant science officer, 2 assistant research officers, 1 technician and 1 administrative assistant (clerk/operation). The observatory has its own human resource development training programme in which the employees discuss how to develop and increase certain skills, such as a training programme for solar observation. In addition, research grants are given to astronomers in the universities for conducting specific research, and, at the same time, providing training to employees at the observatory about the research conducted can also assist them with 'on the job training'. However, the effectiveness is still 50:50, as there are too many training programmes which results in the same staff being burdened with the multiple skills required due to the lack of staff.

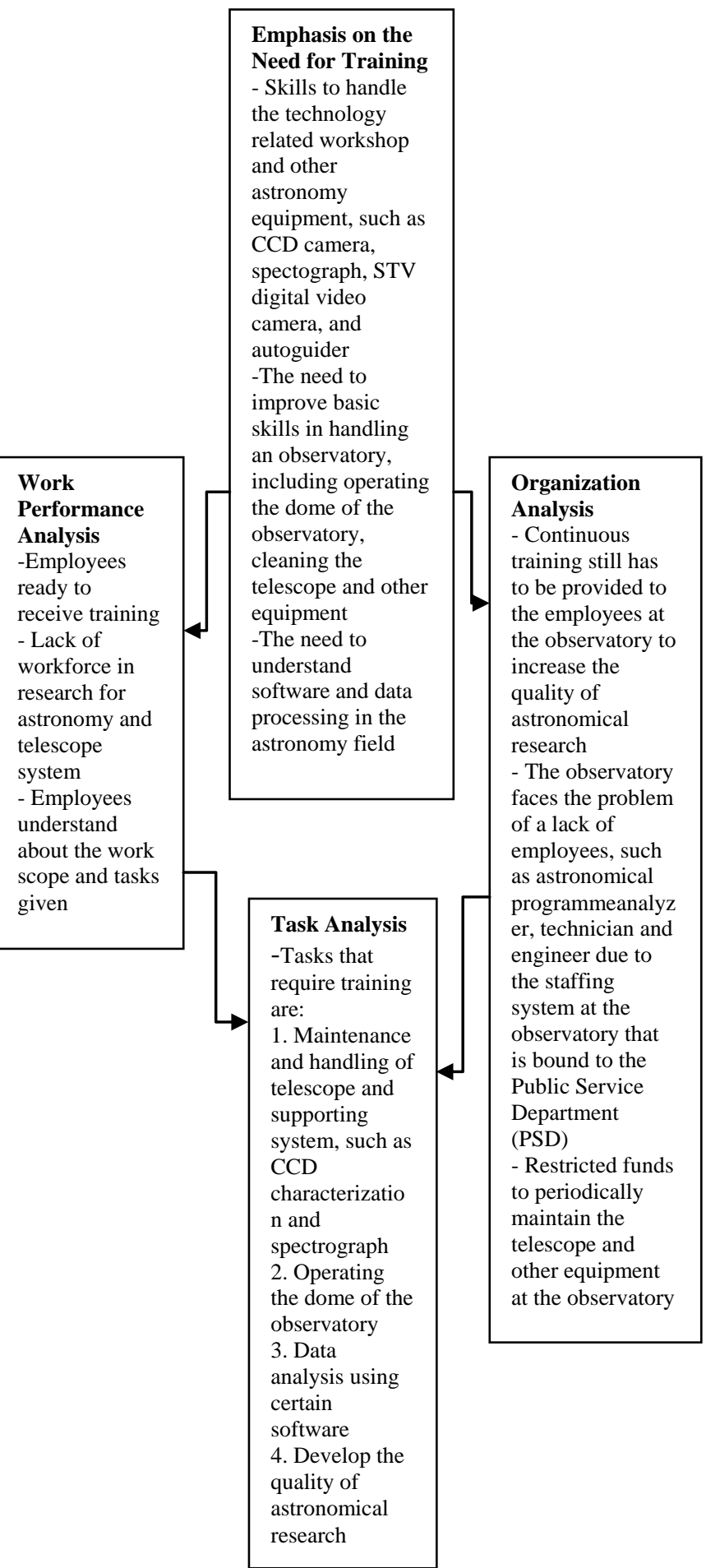

Fig. 2. Analysis for the need of training and development at langkawi national observatory 
TABLE II: REQUIRED POSITIONS AND TASKS AT LANGKAWI NATIONAL OBSERVATORY

\begin{tabular}{|c|c|c|c|}
\hline \multicolumn{2}{|r|}{ Current Positions in Observatory } & \multicolumn{2}{|c|}{ Proposed Future Positions } \\
\hline Positions & Tasks & Positions & Tasks \\
\hline $\begin{array}{l}2 \quad \text { Research } \\
\text { Officers }\end{array}$ & $\begin{array}{l}\text { Perform a variety of tasks including scientific } \\
\text { and management of the observatory, such as } \\
\text { development projects }\end{array}$ & $\begin{array}{l}\text { 6Research Officers, which is a } \\
\text { combination of Research and } \\
\text { Science Officers (Addition of } \\
\text { four people) }\end{array}$ & $\begin{array}{l}\text { Tasks include: } \\
2 \text { persons at stellar system telescope } \\
2 \text { persons at solar system telescope } \\
\text { One person for research theory and } \\
\text { computering } \\
\text { One personfor astronomical instrumentation }\end{array}$ \\
\hline $\begin{array}{l}2 \quad \text { Assistant } \\
\text { Science Officers }\end{array}$ & $\begin{array}{l}\text { Support the routine operation in the } \\
\text { LangkawiNationalObservatory }\end{array}$ & $\begin{array}{l}6 \text { persons (Addition of four } \\
\text { people) }\end{array}$ & $\begin{array}{l}\text { Tasks include: } \\
\text { Support for the observation and data analysis } \\
\text { of stellar system telescope ( } 2 \text { persons) } \\
\text { Support for the observation and data analysis } \\
\text { of solar system telescope ( } 2 \text { persons) } \\
\text { Support for online observation ( } 1 \text { person) } \\
\text { Support the research management that covers } \\
\text { academic programme, tours and data } \\
\text { management ( } 1 \text { person) }\end{array}$ \\
\hline $\begin{array}{l}2 \quad \text { Assistant } \\
\text { Research } \\
\text { Officers }\end{array}$ & & 1 System Engineer Manager & $\begin{array}{l}\text { Managing and ensuring the whole labour } \\
\text { system of observatory is implemented properly }\end{array}$ \\
\hline $\begin{array}{l}1 \text { Administrative } \\
\text { Assistant }\end{array}$ & $\begin{array}{l}\text { Giving support for matters relating to } \\
\text { management and customer service in the } \\
\text { Langkawi National Observatory }\end{array}$ & $\begin{array}{l}3 \text { persons (Addition of two } \\
\text { people) }\end{array}$ & $\begin{array}{l}\text { Scope: } \\
\text { One person to supervise the customer service } \\
\text { and support the role of corporate } \\
\text { communication at the Langkawi National } \\
\text { Observatory } \\
\text { One person to supervise the activities of } \\
\text { management services, such as administration, } \\
\text { finance and, assets }\end{array}$ \\
\hline 1 Technician & $\begin{array}{l}\text { Support the operation and maintenance } \\
\text { programmes in the Langkawi National } \\
\text { Observatory }\end{array}$ & $\begin{array}{l}3 \text { persons including an } \\
\text { engineer and } 2 \text { technicians } \\
\text { (Addition of an engineer and a } \\
\text { technician) }\end{array}$ & $\begin{array}{l}\text { The scope of duties for the mechatronic } \\
\text { engineer is to support the operation and } \\
\text { maintenance of the telescope and dome } \\
\text { system, as well as other scientific } \\
\text { instrumentation. } \\
\text { Meanwhile, for the technicians, one is for the } \\
\text { electrical system, while the other is for the } \\
\text { mechanical and building system (civil) }\end{array}$ \\
\hline & & $\begin{array}{l}1 \text { officer who is skilled in } \\
\text { computer software and } \\
\text { networking systems }\end{array}$ & $\begin{array}{l}\text { Managing IT and software relating to data } \\
\text { analysis in astronomy }\end{array}$ \\
\hline
\end{tabular}

Among the recurring problems that can be seen at the Langkawi National Observatory are the workload and the extra duties of an employee. As an example, a research officer at the Langkawi National Observatory is required to understand and carry out observations at night, and the same person will also undertake the analysis, perform telescope maintenance, as well as fulfilthe daily tasks at the observatory. For example, manage the visitors that come to the observatory during daytime hours. The staffing system that is under the Public Service Department (JPA) also creates minor problems when employing additional staff. The following is a summary of the analysis regarding the need for training and development at the Langkawi National Observatory.

By referring to the figure above, it can be seen that although training has been provided to the employees at the observatory, due to the workload and additional duties falling on the same employee, the training has not met the objective for the outcome from the training conducted. This affects the operation and the increase in thework quality at the observatory. Other than that, the pressure arising from the additional responsibilities faced by the staffs also cause difficulty in solving the tasks within the specified time.

\section{Human Resource DeVElopment Model at the LANGKAWI NATIONAL OBSERVATORY}

The following is a brief proposal for the Human Resource Development model for the Langkawi National Observatory

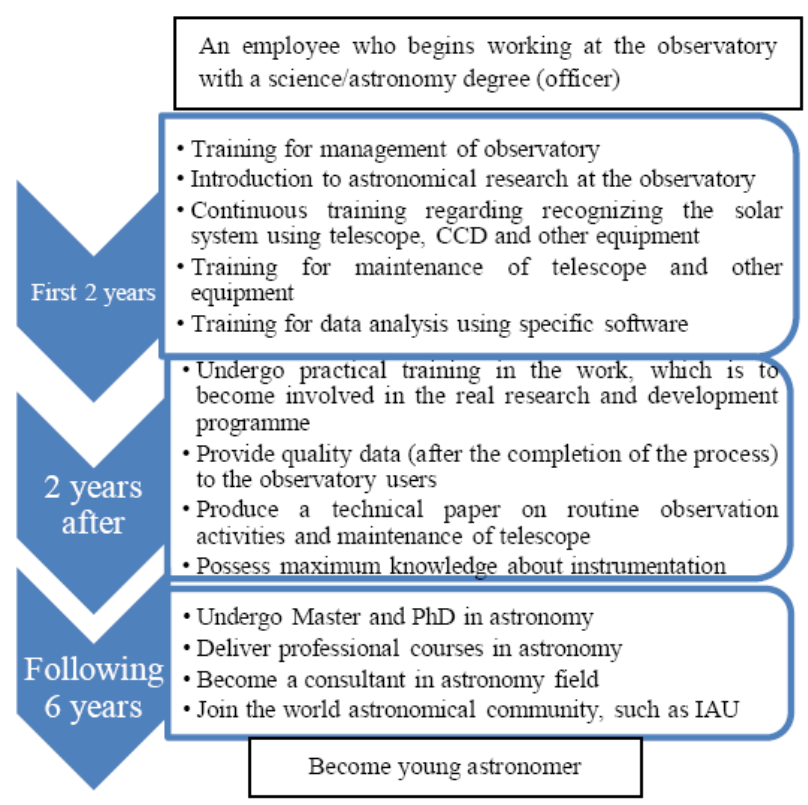

Fig. 3. Proposal of Training Stages

\section{A. Training Process}

Training for staff and employees at the observatory begins with the development of a career path. In the early stage, for good observatory employees and human resources, the cooperation of expert astronomers in Malaysia isessential to provide training to the employees at the observatory. The recommendations in Fig. 3 are proposed as 
the training route to develop their expertise

\section{B. Staffing System}

The Table II shows the positions and tasks that must be present at the Langkawi National Observatory.

\section{CONCLUSION}

The proposed human resource development model is a mechanism for developing human resources at the observatory. The training process and staffing system should be improved to ensure the effectiveness of the research and maintenance of astronomy equipment at the Langkawi National Observatory (LNO), particularly. When an observatory has skilled, trained and adequate workforce, the issues mentioned previously can be suitably handled.

\section{REFERENCES}

[1] L. Naicker and K. Govender, "Towards a Global Baseline for Astronomy Development," CAP (Communicating Astronomy with the Public Journal), vol. 7, pp. 14, November 2009.

[2] S. Man et al., "The Development of Islamic Astronomy Studies in Higher Learning Institutions in Malaysia," Middle-East Journal of Scientific Research(MEJSR), vol. 12, no. 1, pp. 108-113, Special Issue 2012.

[3] S. Azhari, "PerkembanganKajianAstronomiIslam di AlamMelayu," Journal of Fiqh, no. 7, pp. 181-183, 2010.

[4] A. A. Yusof, Pengurusan Sumber Manusia: Konsep, IsudanPelaksanaan, $3^{\text {rd }}$ Edition, Malaysia, Pearson Malaysia Sdn. Bhd, pp. 38.

[5] Dasar Sains dan Teknologi Negara Website. (22 July 2013). [Online]. Available: http://pmr.penerangan.gov.my/index.php/maklumatkenegaraan/247-dasar-sains-dan-teknologi-negara.html

[6] Cascio, Managing Human Resources: Productivity, Quality of Work Life, Profits, Seventh Edition, McGraw-Hill International Edition, New York, 2006, pp. 199.

[7] I. Ridpath, A Dictionary of Astronomy, New York, Oxford University Press, 1997, pp. 334.

[8] V. Illingworth, The Macmillan Dictionary of Astronomy, London, The Macmillan Press LTD, hlm, 1979, pp. 226.

[9] Glosari Astronomiterbitan Dewan Bahasadan Pustakatahun 1995, Kuala Lumpur, ch. 250.

[10] M. Z. Zainuddin, "Institusi Balai Cerap: Peranannya dalam Pendidikan, Penyelidikan dan Pelancongan," Koleksi Kertas Kerja Seminar Persatuan Falak Syari'i (1406H/1986M - 1425H/2004M), Kuala Lumpur, Persatuan Falak Syari'i Malaysia, ch. 481, 2002.

[11] K. Sains, Teknologi dan Inovasi (MOSTI), Galeria Astronomi Observatori Malaysia, 2009, pp. 2.

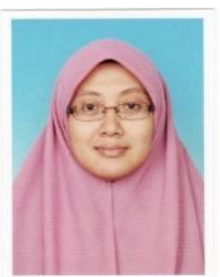

Khadijah Ismail is currently a fellow in the Islamic Astronomy Programme, Department of Fiqh and Usul, Academy of Islamic Studies, University of Malaya, Malaysia. She was born in Johor, Malaysia, on 16 April 1982. In 2006, she gained a Bachelor in Islamic Astronomy from the Academy of Islamic Studies, University of Malaya and pursued her studies in the Faculty of Science at the University of Malaya. She acquiredher Master of Science Degree in 2010 and is currently pursuing her PhD in the Department of Islamic History and Civilization in Academy of Islamic Study, University of Malaya, in the field of Development in Islamic Astronomy.

She has experience in teaching tutorial subjects in Islamic astronomy in the University of Malaya, such as History of Islamic Astronomy, General Astronomy, Crescent Observation Practical Theory, Calculation Concept of Qiblah Direction and Prayer Times and Science Physics Foundation 1 and 2. She has published four chapters in books and four articles in journals including Khadijah Ismail et al., "Application of Scientific Approach to Determine Lunar Crescent's Visibility”, Middle East Journal of Scientific Research, No. 12, 2012; and Khadijah Ismail et al., Kajian Pembangunan Sumber Manusia dan Penyelidikan di Balai Cerap Maragha (1259M 1316M)" in Tradisi Kecemerlangan Astronomi Islam, 2013, Kuala Lumpur: Jabatan Fiqh dan Usul.

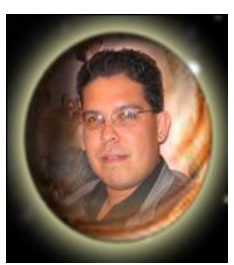

Fairos Asillam has acted as a Coordinator of the Langkawi National Observatory (LNO) from January 2008 and has served as a Head of the Space Science Research Unit (UPSA), Malaysia, from January 2008 until March 2012. He was born in Kedah, Malaysia on 5 February 1974. In 1998, he gained a Bachelor of Science from the University of Malayain Physics and is now pursuing his studies in the National University of Malaysia. His experience and specialization includes space science and microgravity management, and space science education.

He has considerable experience in presenting papers as a speaker.He cowrote and presented a paper on "Near Equatorial Satellite Orbit, (NEqO)" in a Symposium on Microsatellite Applications for Asia Pacific in Canberra, Australia from 21 - 24 May 2000, co-wrote a paper on "Internet Based Education Recourses, (IBER)" in Telescope Seminar 2000 in the National Planetarium, Malaysia, and a paper on "Solar Maximum 2000" in a Workshop on Laboratory Technology 2001 in the National University of Malaysia.

He has a Certificate for successfully completing studies in a short term training course of Space Technology and Remote Sensing Application for Asia Pacific Multilateral Cooperation in Space Technology and Applications organized by the China National Space Administration (CNSA) from 11 July to 10 August 2002 and a Certificate for excellent service in 2001 from the Ministry of Science, Technology and Environment Malaysia.

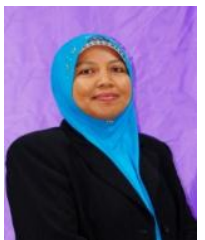

Aizan Ali Mat Zin is Malaysian, and currently is a senior lecturer in the Department of Islamic History and Civilization, Academy of Islamic Studies, University of Malaya, Malaysia. She graduated from University of Malaya in 1996 and earned a 1st class honours for her Bachelor of Usuluddin. In 1998, she gained her MA from the School of Oriental and African Studies (SOAS), University of London, and her $\mathrm{PhD}$ in 2010 from the University of Wales, United Kingdom.

Her area of study is Islamic Civilization focusing on Islamic Development, Muslim Scholars Biographical Studies, Islamic Institution of Education, and Islamic Architecture. She has considerable experience in presenting papers both abroad and local since her postgraduate days including BRISMES at the Edinburgh University, United Kingdom, in 2006; WOCMES at De Autonoma Universitat, Barcelona, Spain, in 2010; the University of Muhammadiyah, Jakarta, Indonesia, in 2011 and KUPUSB, Brunei, in 2012. She has published several of her works including Islamic Institutions of Education in British India: A Study on Deoband Madrasah, Jurnal Usuluddin APIUM 9:113-132, Al-Attas's Works and Contribution to the Islamic Architecture in Malaysia, MiddleEast journal of Scientific Research 14 (12):1685-1690, 2013 (ISSN 19909233), and Islamic Institution of Higher Education in Malaysia: Issues and Challenges in Developing Muslim Intellectuals, KUPUSB, 2012 (ISBN 99917-44-99-1). She was awarded a Certificate of excellent service by the University of Malaya in 2001 and is active in the mass media forum in television and magazines in Malaysia. 